\begin{abstract}
We present data on the morphology of the larval stages of lanternfish species (Myctophidae) in the central North Atlantic Ocean. This work is based on materials collected during 2 cruises in the North Atlantic Ocean from the equator to latitude $30^{\circ} \mathrm{N}$ in 2016 and 2018. Several larvae obtained in other geographical areas were used for identification. In total, at least 33 species of the Myctophidae were found in the study area. We provide descriptions of those species whose early development was not previously known and of those species whose morphology differs from those already described in literature: roundnose lanternfish (Centrobranchus nigroocellatus), stubby lanternfish (Bolinichthys supralateralis), Diaphus sp. 1, Nannobrachium sp. 1, noble lanternfish (Lampanyctus vadulus), and Lampanyctus sp. 1. The characteristics on which these determinations are based are discussed.
\end{abstract}

Manuscript submitted 7 November 2019. Manuscript accepted 5 May 2020. Fish. Bull. 118:135-144 (2020). Online publication date: 15 May 2020. doi: 10.7755/FB.118.2.3

The views and opinions expressed or implied in this article are those of the author (or authors) and do not necessarily reflect the position of the National Marine Fisheries Service, NOAA.

\title{
Ichthyoplankton of the central North Atlantic Ocean: larval development of lanternfish species (Pisces: Myctophidae)
}

\author{
Yana Yu. Bolshakova (contact author) \\ Sergei A. Evseenko \\ Email address for contact author: yanusrunaa@mail.ru \\ P. P. Shirshov Institute of Oceanology \\ Russian Academy of Sciences \\ 36 Nakhimovskyi Prospekt \\ Moscow 117997, Russia
}

Lanternfish (family Myctophidae) are the main part of the trophic chain of oceanic fish species and play a significant role in the feeding of commercially important species (Nafpaktitis et al., 1977; Sabourenkov, 1992; Kozlov, 1995). Because some species of lanternfish form large schools at certain periods of their life, this family can be considered to include prospective species for fisheries in the future (Ahlstrom et al., 1976; Valinassab et al., 2007). At least 80 species of myctophids inhabit the waters of the central North Atlantic Ocean, and early life stages are known for only $60 \%$ of these species. At least 33 taxa of Myctophidae belonging to 15 genera were caught in 2 complex faunistic expeditions conducted by the Institute of Oceanology, Russian Academy of Sciences (IO RAS), to the North Atlantic Ocean: the 39th voyage of the RV Professor Logachev and the 43rd voyage of the RV Akademik Vavilov. Larval identification is complicated by small specimens and the absence of transforming stages. Still, 28 of the 33 taxa were identified to the species level.

In earlier work, we considered the species composition and distribution of ichthyoplankton, including the larvae of lanternfish collected during 43 voyages (Bolshakova and Evseenko, 2020). This article presents larval descriptions for species and genus-level types previously undescribed for the region, including the stubby lanternfish (Bolinichthys supralateralis) and the roundnose lanternfish (Centrobranchus nigroocellatus), and for taxa, such as Diaphus sp. 1, Nannobrachium sp. 1, and Lampanyctus spp., for which determination poses difficulties.

\section{Materials and methods}

Early developmental stages of fish sampled during the 43rd expedition of the RV Akademik Vavilov and the 39th expedition of the RV Professor Logachev served as materials for the work we present here. A representative faunistic collection of ichthyoplankton and adult fish was taken in the cross-section between latitude $30^{\circ} \mathrm{N}$ and the equator in October 2016 and in a polygon in the central part of the North Atlantic Ocean in March 2018 (Fig. 1). Additionally, materials from the collections of the 29th expedition of the RV Akademik Ioffe to the central and South Atlantic Ocean and the 36th expedition of the RV Akademik Kurchatov to the West Indian Ocean were used (Table 1). The ichthyoplankton was sampled by using an Isaacs-Kidd mid-water trawl with 


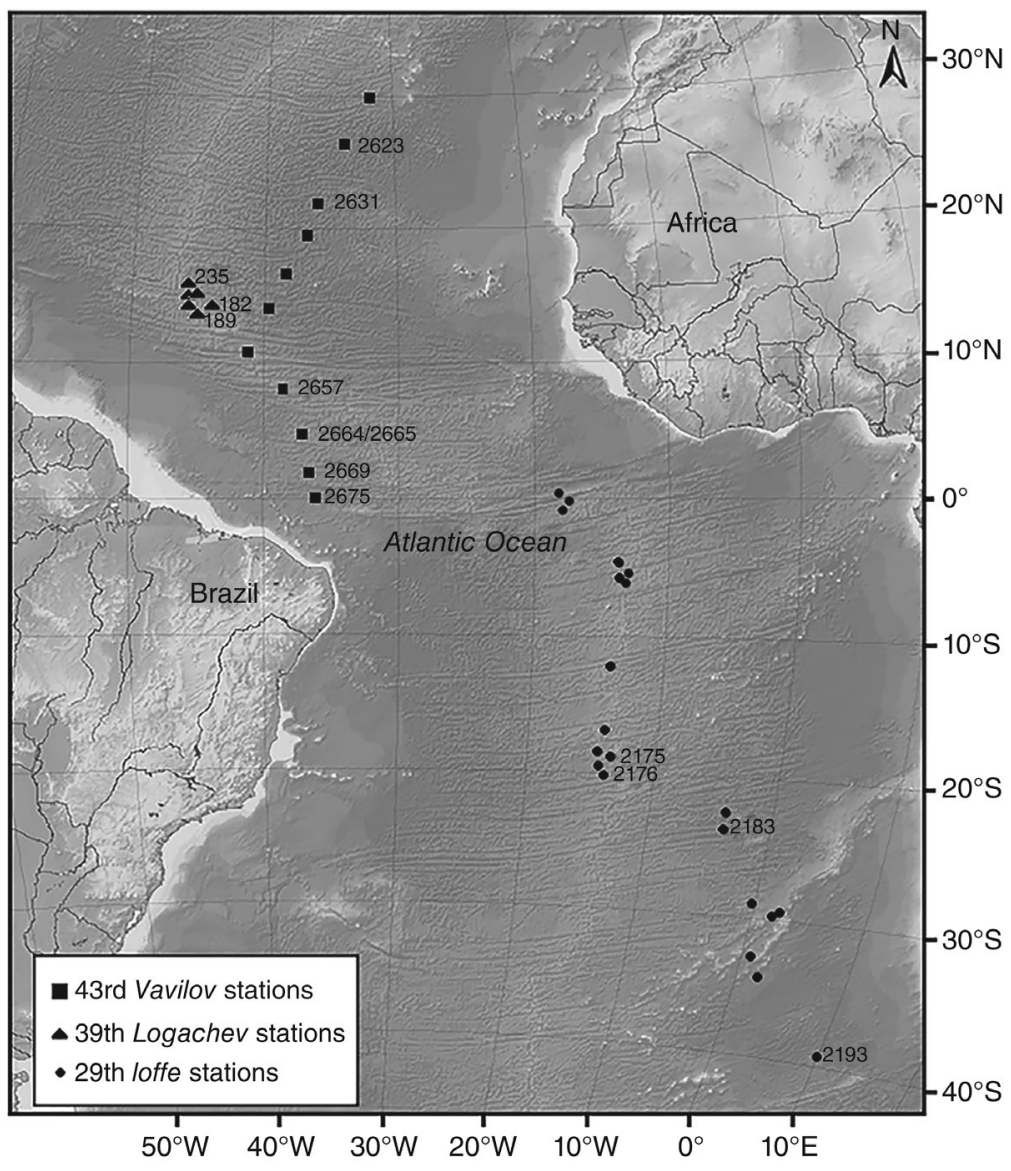

Figure 1

Map of the study area showing the locations of the all the stations sampled during the 43rd expedition of the RV Akademik Vavilov, 39th expedition of the RV Professor Logachev, and 29th expedition of the RV Akademik Ioffe across the Atlantic Ocean. A representative faunistic collection of ichthyoplankton and adult fish was taken during the expeditions of the RV Vavilov and of the RV Professor Logachev from the equator to latitude $30^{\circ} \mathrm{N}$ in 2016 and 2018. Larvae were also obtained for identification purposes from the collection of the expedition of the RV Ioffe to the central and South Atlantic Ocean in 2009. The numbers next to station markers are given for stations where larval lanternfish (Myctophidae) examined for this study were found. The coordinates of the stations and the dates of capture are provided in Table 1.

(PAL), predorsal length (PDL), snout length (SnL), horizontal diameter of the eye (ED), number of rays in dorsal fin (D), number of rays in anal fin (A), number of rays in pectoral fin $\left(\mathrm{P}_{1}\right)$, number of rays in pelvic fin $\left(\mathrm{P}_{2}\right)$, number of rays in caudal fin $(\mathrm{C})$, number of branchiostegal rays $(\mathrm{BrR})$, number of gill rakers on the upper and lower parts of the first gill arch (GR), number of vertebrae (V), 2nd branchiostegal photophore $\left(\mathrm{Br}_{2}\right)$, 5th pectoral photophore $\left(\mathrm{PO}_{5}\right)$, and suborbital photophore (So).

\section{Results and discussion}

\section{Centrobranchus nigroocellatus}

Description Two larvae were identified in our collections: $4.1 \mathrm{~mm}$ SL (station [st.] 2675), $12.2 \mathrm{~mm} \mathrm{SL}$ (st. 182) (Fig. 2). D: $11, \mathrm{~A}: 16, \mathrm{P}_{1}: 15, \mathrm{P}_{2}: 8, \mathrm{C}: 6+10-9+5$, GR: 0, V: 38-39, BrR: 8 . The early 4.1mm-SL larva has a deep body (BD 36\% $\mathrm{SL})$, laterally compressed with thin caudal peduncle. The head is large (HL $35 \%$ $\mathrm{SL}$, the upper profile of the head is convex, and the snout protrudes above the lower jaw (SnL 34\% HL). Oval eyes have a cone-shaped appendage of choroid tissue (ED 15\% HL). The jaws are long, and the angle of the mouth reaches the vertical of the eye posterior margin. The gut is relatively straight, and the anus opens behind the middle of the body (PAL 67\% SL). The larva has dorsal- and ventralfin folds. The pectoral fins are fan-shaped and large. Rays in pectoral and ventral fins have not yet been formed. Ray formation in unpaired fins has already begun: in the caudal fin, there are $5+6$ main rays, the dorsal fin starts slightly behind the middle of the body (PDL 59\% SL) and has 7+ rays (larva torn), and the

the Samyshev-Aseev modification. This trawl is $25 \mathrm{~m}$ long and has a 5-mm mesh net without nodes and with a terminal insertion of $500-\mu \mathrm{m}$ nylon mesh and a $6-\mathrm{m}^{2}$ mouth area. Illustrated monographs for different areas of the Atlantic Ocean were used for identification: western central (Richards, 2005), northwest (Fahay, 2007), southeast (Olivar and Fortuño, 1991), and southwest (Bonecker and de Castro, 2006). The specimens were preserved and stored in $4 \%$ formaldehyde. The larvae were stained with alizarin following the standard procedure. All illustrations given in this paper are original.

Information for the following features are included in the descriptions: standard body length (SL), head length (HL), body depth at pectoral fin base (BD), preanal length anal fin is behind the vertical of the middle of the dorsal fin and has 16 rays formed in it. Pigmentation of the larva includes an unpaired melanophore between the forebrain and midbrain, at the posterior edge of the orbit above the otic capsules, and at the distal edge of the gill cover. There is scattered pigment on the branchiostegial rays. Paired melanophores are above the anterodorsal margin of the pectoral fin base, and a dorsolaterally located melanophore is above the middle part of the gut. $\mathrm{Br}_{2}$ photophores in a small larva are already formed. The body proportions of the 12.2-mm-SL larva vary slightly (BD 29\% SL, HL $25 \%$ SL, 36\% HL, ED 19\% HL, PAL 61\% SL, PDL 53\% SL). The ventral fin fold almost completely disappears, and the fins have a definitive number of rays. The conical 


\begin{tabular}{|c|c|c|c|c|}
\hline \multicolumn{5}{|c|}{ Table 1} \\
\hline \multicolumn{5}{|c|}{$\begin{array}{l}\text { The stations, dates, coordinates, and depth layers of the } 4 \text { expeditions during which the larval lan- } \\
\text { ternfish (Myctophidae) examined for this study were caught. A representative faunistic collection of } \\
\text { ichthyoplankton and adult fish was taken during the expeditions of the RV Akademik Vavilov in the } \\
\text { cross-section between latitude } 30^{\circ} \mathrm{N} \text { and the equator in } 2016 \text { and of the RV Professor Logachev in the } \\
\text { central part of the North Atlantic Ocean in } 2018 \text {. Additional materials were obtained from the collec- } \\
\text { tions of the expeditions of the RV Akademik Ioffe to the central and South Atlantic Ocean and of the } \\
\text { RV Akademik Kurchatov to the west Indian Ocean. }\end{array}$} \\
\hline $\begin{array}{l}\text { Research vessel } \\
\text { (expedition no.) }\end{array}$ & $\begin{array}{c}\text { Station } \\
\text { no. }\end{array}$ & Date & Coordinates & $\begin{array}{l}\text { Depth } \\
\text { layer }\end{array}$ \\
\hline \multirow[t]{8}{*}{ Akademic Vavilov (43) } & 2623 & 14 October 2016 & $26^{\circ} 34^{\prime} 36^{\prime \prime} \mathrm{N}, 33^{\circ} 55^{\prime} 12^{\prime \prime} \mathrm{W}$ & $0-200$ \\
\hline & 2631 & 16-17 October 2016 & $22^{\circ} 2^{\prime} 36^{\prime \prime} \mathrm{N}, 35^{\circ} 52^{\prime} 12^{\prime \prime} \mathrm{W}$ & $0-700$ \\
\hline & 2657 & 24 October 2016 & $08^{\circ} 13^{\prime} 54^{\prime \prime} \mathrm{N}, 38^{\circ} 24^{\prime} 0^{\prime \prime} \mathrm{W}$ & $0-700$ \\
\hline & 2662 & 25 October 2016 & $4^{\circ} 46^{\prime} 18^{\prime \prime} \mathrm{N}, 37^{\circ} 12^{\prime} 18^{\prime \prime} \mathrm{W}$ & $0-200$ \\
\hline & 2664 & 25 October 2016 & $4^{\circ} 45^{\prime} 54^{\prime \prime} \mathrm{N}, 37^{\circ} 9^{\prime} 18^{\prime \prime} \mathrm{W}$ & $0-200$ \\
\hline & 2665 & 25-26 October 2016 & $4^{\circ} 43^{\prime} 30^{\prime \prime} \mathrm{N}, 37^{\circ} 8^{\prime} 42^{\prime \prime} \mathrm{W}$ & $0-700$ \\
\hline & 2669 & 26-27 October 2016 & $2^{\circ} 2^{\prime} 30^{\prime \prime} \mathrm{N}, 36^{\circ} 32^{\prime} 12^{\prime \prime} \mathrm{W}$ & $0-700$ \\
\hline & 2675 & 27-28 October 2016 & $0^{\circ} 1^{\prime} 0^{\prime \prime} \mathrm{S}, 36^{\circ} 1^{\prime} 6^{\prime \prime} \mathrm{W}$ & $0-700$ \\
\hline \multirow[t]{3}{*}{ Professor Logachev (39) } & 182 & 27 February 2018 & $14^{\circ} 37^{\prime} 54^{\prime \prime} \mathrm{N}, 44^{\circ} 56^{\prime} 12^{\prime \prime} \mathrm{W}$ & $0-1500$ \\
\hline & 189 & 1 March 2018 & $13^{\circ} 52^{\prime} 48^{\prime \prime} \mathrm{N}, 45^{\circ} 0^{\prime} 36^{\prime \prime} \mathrm{W}$ & $0-700$ \\
\hline & 235 & 15 March 2018 & $16^{\circ} 18^{\prime} 42^{\prime \prime} \mathrm{N}, 46^{\circ} 41^{\prime} 24^{\prime \prime} \mathrm{W}$ & $0-700$ \\
\hline \multirow[t]{4}{*}{ Akademic Ioffe (29) } & 2175 & 11 November 2009 & $15^{\circ} 45^{\prime} 59^{\prime \prime} \mathrm{S}, 13^{\circ} 13^{\prime} 5^{\prime \prime} \mathrm{W}$ & $0-225$ \\
\hline & 2176 & 12 November 2009 & $18^{\circ} 0^{\prime} 10^{\prime \prime} \mathrm{S}, 13^{\circ} 21^{\prime} 26^{\prime \prime} \mathrm{W}$ & $0-350$ \\
\hline & 2183 & 18 November 2009 & $25^{\circ} 42^{\prime} 39^{\prime \prime} \mathrm{S}, 2^{\circ} 21^{\prime} 54^{\prime \prime} \mathrm{W}$ & $0-250$ \\
\hline & 2193 & 26 November 2009 & $36^{\circ} 56^{\prime} 43^{\prime \prime} \mathrm{S}, 7^{\circ} 19^{\prime} 17^{\prime \prime} \mathrm{E}$ & $0-550$ \\
\hline \multirow[t]{2}{*}{ Akademik Kurchatov (36) } & 3708 & 19 March 1983 & $1^{\circ} 3^{\prime} 18^{\prime \prime} \mathrm{N}, 56^{\circ} 19^{\prime} 18^{\prime \prime} \mathrm{E}$ & $0-500$ \\
\hline & 3737 & 2 April 1983 & $10^{\circ} 35^{\prime} 6^{\prime \prime} \mathrm{S}, 50^{\circ} 51^{\prime} 0^{\prime \prime} \mathrm{E}$ & $0-500$ \\
\hline
\end{tabular}

appendage is long and reaches the upper jaw. Pigmentation changes somewhat: the melanophores disappear above the brain, the gut, and pectoral fin. More melanophores appear on the ventrolateral margin of the orbit, behind the olfactory capsules and on the isthmus; a line occurs on the ventral surface of the liver. $\mathrm{PO}_{5}$ photophores begin to form.

Comparative remarks Only one species of Centrobranchus (C. nigroocellatus) is found in waters of the Atlantic Ocean (Hulley, 1981; Bekker, 1983). The development of this species in the Pacific Ocean has been described in detail (Pertseva-Ostroumova, 1964; Moser and Ahlstrom, 1970, 1996). Our 4.1-mm-SL larva has a greater body height and a larger head compared with similarly sized larvae (6.1 mm SL) from California (BD 36\% SL vs. $23 \%$, HL $35 \%$ SL vs. 27-30\%). In addition, larvae from the Pacific Ocean have a later start to the formation of rays in the $\mathrm{C}, \mathrm{D}$, and $\mathrm{A}$ (with SL about $5 \mathrm{~mm}$ ). There are also differences in the pigmentation of the larvae from California: at $\mathrm{SL}<5 \mathrm{~mm}$, they have melanophores at the tips of both jaws, at the terminal gut section, and at the olfactory lobes of the brain, melanophores that are absent in our early larva. The pigmentation and proportion features of the 12.2-mm-SL larva correspond to those observed for larvae of a similar size from the Pacific Ocean. Although our larvae have some differences from those described in earlier reports, these differences apparently are due to the geographical variability of the species.

\section{Bolinichthys supralateralis}

Description Six larvae were collected: $4.6 \mathrm{~mm} \mathrm{SL} \mathrm{(st.}$ 2664), $8.2 \mathrm{~mm}$ SL (st. 2669), $10.5 \mathrm{~mm}$ SL (st. 2664), 11.5 mm SL, 11.5-mm SL, 11.9 mm SL (st. 189) (Fig. 3). D: 12, A: 14, $\mathrm{P}_{1}: 14, \mathrm{P}_{2}: 8, \mathrm{C}: 5+9-10+5$, GR: $(6) 5+1+14(15)=20$ 22 , V: 33-34, BrR: 9. The 4.6-mm-SL early larva is relatively deep-bodied (BD $22 \% \mathrm{SL}$ ), the head is relatively large (HL 30\% SL), and the eyes are round and very large (ED $41 \% \mathrm{HL}$ ). The snout is rather blunt and short (SnL $26 \% \mathrm{HL}$ ), and the jaws almost reach the vertical of the posterior margin of the eye. There are teeth on both jaws. The intestine is wide and relatively straight, and the anus opens behind the middle of the body. The pectoral fins are large, and the rays in it are not yet formed. The dorsal fin originates in the middle of the body (PDL 50\% SL), and the anal fin starts under the end of the dorsal fin (PAL $63 \% \mathrm{SL}$ ). Rays in the fins are not yet formed: in the dorsal and anal fins, pterygiophores are observed, and in the caudal fin there are rays only in the epaxial lobe. The larva is 

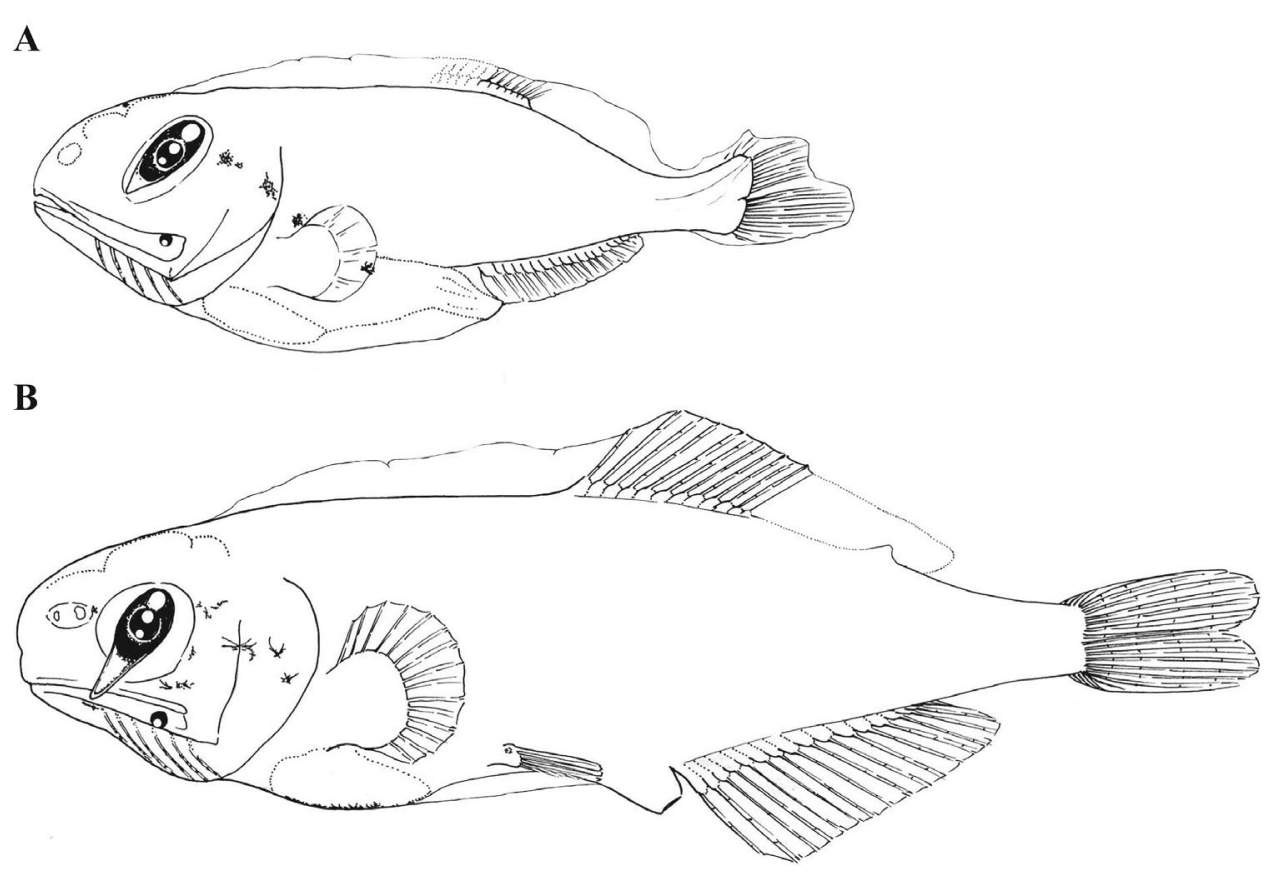

Figure 2

Illustrations of 2 early developmental stages of larval roundnose lanternfish (Centrobranchus nigroocellatus) caught in the central North Atlantic Ocean (A) at station 2675 in 2016 (4.1 mm standard body length [SL]) and (B) at station 182 in 2018 (12.2 mm SL).

poorly pigmented: there are paired small melanophores above the midbrain, and the internal pigment is located at the level of the otic capsule, above the gas bladder and above the terminal gut section. There are no photophores in the 4.6-mm-SL larva. With an increase in the size of larvae, the height of the body and the anteanal distance slightly increase. Otherwise, the proportions are preserved (BD 27\% SL, HL 30\% SL, ED 39\% HL, SnL 26\% HL, PAL $67 \%$ SL, PDL 50\% SL). Pigmentation of the larvae persists. Melanophores located above the midbrain posterior margin enlarge and merge to form a band. $\mathrm{Br}_{2}$ photophores are formed.

Comparative notes The larvae of $B$. distofax, B. longipes, B. pyrsobolus, and some Bolinichthys spp. have been described (Pertseva-Ostroumova, 1964; Moser and Ahlstrom, 1972, 1996; Olivar et al., 1999). Only 7 species of the genus are known: B. distofax, B. indicus, B. photothorax, B. supralateralis, B. longipes, B. nikolayi, and B. pyrsobolus (Hulley and Duhamel, 2009). The last 3 species are not found in the Atlantic Ocean. Of the 4 species living in the investigated area, the species most similar to specimens from our sampling are $B$. photothorax and B. supralateralis, according to the number of gill rakers (19-23); in contrast, the remaining 2 species (B. distofax and $B$. indicus) have $\leq 18$ rakers. Larvae of a similar size and similar in pigmentation to our specimens are described from the Agulhas Current, which forms the western boundary current of the southern Indian Ocean, as Bolinichthys spp. (Olivar et al., 1999). Olivar et al. (1999) suggest that their larvae may belong to 1 of 2 species: $B$. indicus or $B$. supralateralis, which inhabit waters off the eastern coast of southern Africa. We excluded B. photothorax because this species does not occur in the Indian Ocean south of latitude $30^{\circ} \mathrm{S}$, specifically not in the Agulhas Current (Bekker, 1983; Hulley and Duhamel, 2009). The larvae from waters of the southeast Pacific Ocean identified as B. pyrsobolus (Pertseva-Ostroumova, 1964) are practically no different from our larvae, but this species does not inhabit the Atlantic Ocean. On the basis of the foregoing, we preliminarily identified our larvae as B. supralateralis.

\section{Diaphus sp. 1}

Description Two larvae were identified in our sampling: $3.6 \mathrm{~mm}$ SL (st. 2665), $5.7 \mathrm{~mm}$ SL (st. 2665) (Fig. 4). D: 15?, A: 16, $\mathrm{P}_{1}: 9+, \mathrm{P}_{2}: 6+, \mathrm{C}: 6+10-9+5$, GR: $10+, \mathrm{V}: 37$, BrR: 8. Larvae are relatively deep-bodied and short (BD 21-29\% SL), with a relatively large head (HL 33-34\% SL). The gut is fairly slender, and the anus opens slightly behind the midbody (PAL 56-63\% SL); dorsal fin begins in the middle of the body (PDL 49-50\% SL). The eyes are slightly oval and become round with an increase in the length of the larva (ED 31-36\% HL). One melanophore is situated anteriorly on the ventral gut margin at 

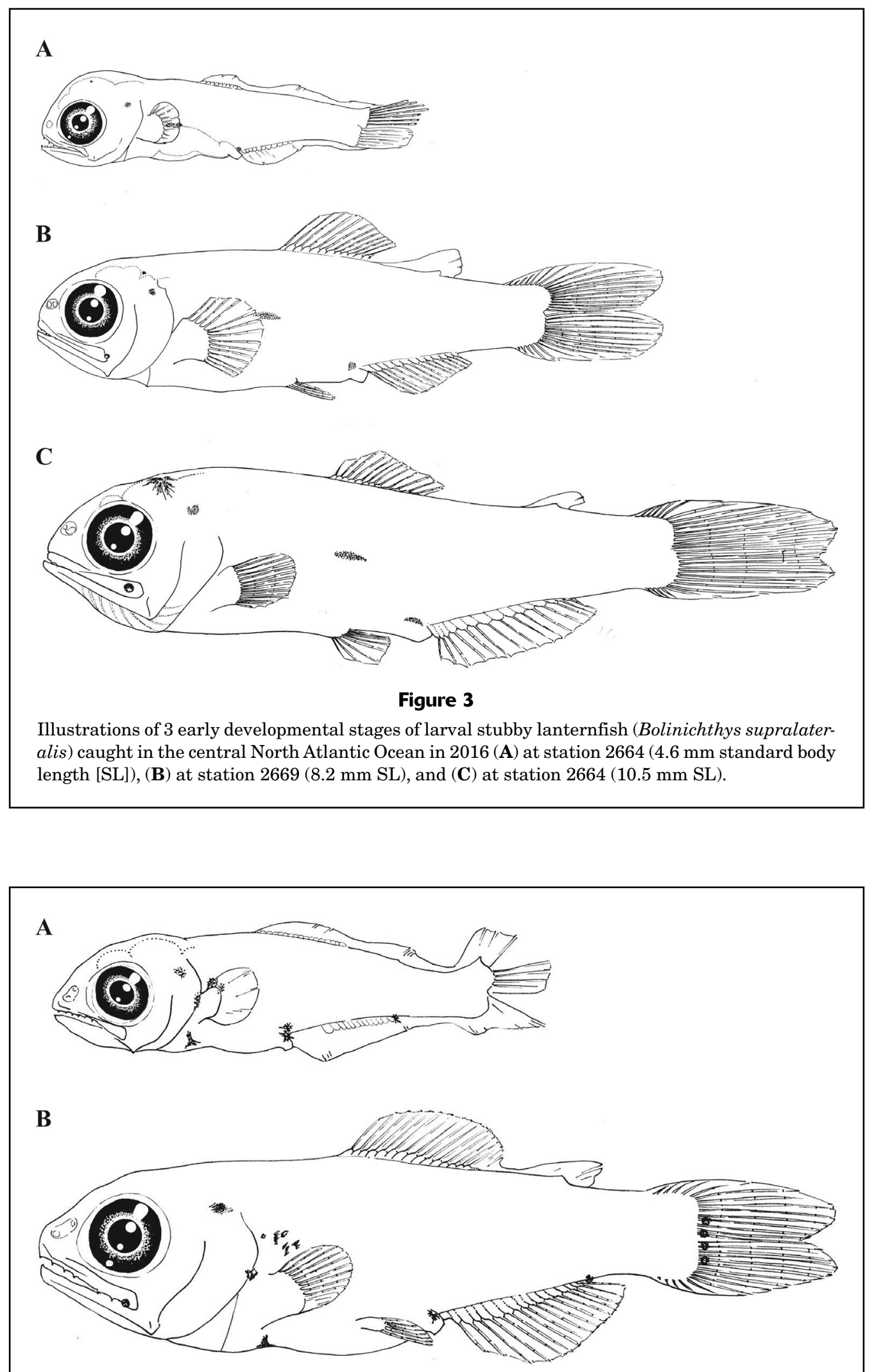

Figure 4

Illustrations of 2 early developmental stages of larval Diaphus sp. 1 caught in the central North Atlantic Ocean in 2016 at station 2665: (A) $3.6 \mathrm{~mm}$ standard body length (SL) and (B) $5.7 \mathrm{~mm}$ SL. 
the pectoral fin level; a pair are located dorsally on the terminal gut section and posteriorly to the anal fin base end, and one is on the cleithrum. Inner melanophores are noticeable above the otic capsule and above the gas bladder. With increased size of the larva, melanophores above the gas bladder spread to myosepta and a vertical row of the caudal fin rays, typical of the genus, is added. The 5.7-mm-SL larva has a $\mathrm{Br}_{2}$ photophore symmetrically on both sides of its body.

Comparative remarks The described larvae belong to the moderately deep-bodied Diaphus larval type (Moser et al., 1984). In larvae of this morphotype, So photophores do not form in adults. At least 11 species of Diaphus without So photophores inhabit the equatorial Atlantic Ocean (Hulley, 1981), and only one of these species-D. metapoclampus-has a larval description (Sparta, 1952). Larvae similar to our specimens have been described by Moser and Watson (2001) as Diaphus sp., with the differences being in the presence of a melanophore on each side of midgut in early larvae and in the lack of melanophores on myosepta. Similar larvae also have been described by Ozawa (1986) as Diaphus sp. 11. The identification of all known Diaphus larvae is based on a serial method that uses the location of photophores in juveniles. However, early larvae with similar morphology, pigmentation, and meristic characters may turn out to be a complex of species that are almost impossible to distinguish because of the lack of photophores (Ozawa, 1986; Olivar and Beckley, 1997). Therefore, we identified these larvae only to the genus.

\section{Nannobrachium sp. 1}

Description Two larvae were identified in our collections: $4.0 \mathrm{~mm}$ SL (st. 2662), $8.0 \mathrm{~mm}$ SL (st. 2183) (Fig. 5). D: 13, A: 17, $\mathrm{P}_{1}: 13, \mathrm{P}_{2}: 8$, C: 5+9-9+5, GR: $10+$, BrR: 8 . The 4.0-mm-SL larva has a deep body (BD $39 \%$ SL). The head is large, taking almost half of the body length (HL $44 \%$ SL), with an elongated, pointed rostrum (SnL 37\% HL). Eyes are round (ED 33\% HL). The jaws are long and end behind the vertical of the eye middle. The pectoral fins are fan-shaped. The gut is wide and relatively straight, and the anus opens far behind the midbody (PAL 73\% SL). The dorsal fin begins slightly behind the middle of the body (PDL 63\% SL), and the anal fin begins under the end of the dorsal fin. Pigmentation of the head includes minute melanophores at the tips of the jaws, paired melanophores anterior to the midbrain, unpaired melanophores above the forebrain, and one melanophore each posterior to the midbrain and to the hindbrain. There are several melanophores on the opercle and on the cleithrum. The inner side of the pectoral fin's base and the base of the pectoral and ventral fin rays are pigmented. Internal melanophores are noticeable in the middle part of the horizontal septum, as well as on the myosepta of the oblique muscle of the

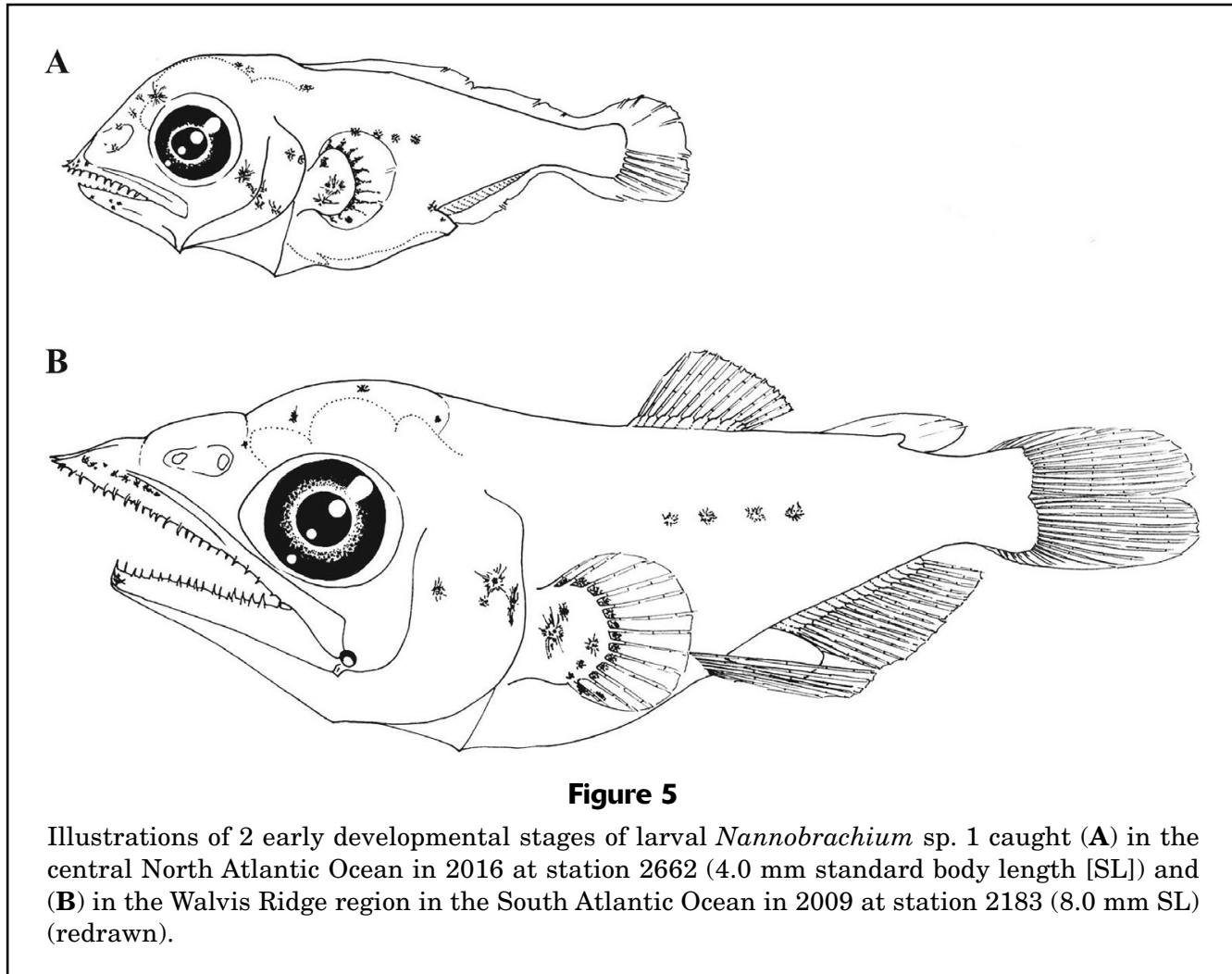


abdomen. $\mathrm{Br}_{2}$ photophores are not yet formed. Morphology of the 8.0-mm-SL larva has been described earlier (we previously identified this specimen as Nannobrachium wisneri in Bolshakova and Evseenko, 2016, by counting characters and considering the place of capture). In general, the pigmentation pattern has not changed. Body depth, eye diameter, and predorsal length are decreased; anteanal and snout length are increased (BD 31\% SL, HL $45 \%$ SL, SnL $45 \%$ HL, ED $24 \%$ HL, PAL 78\% SL, PDL $58 \%$ $\mathrm{SL})$. There are $\mathrm{Br}_{2}$ photophores.

Comparative remarks There are several opinions about phylogenetic relationships within the genus Lampanyctus. One opinion is that the genus Nannobrachium is a junior synonym of Lampanyctus; other authors recognize its validity (Bekker, 1983; Moser and Ahlstrom, 1996; Olivar and Beckley, 1997; Zahuranec, 2000). According to the latest information (Kobyliansky, 2016), there are no osteological differences between groups within the genus Lampanyctus, confirming the opinion of monophyly of this genus. In spite of this notion of monophyly, here, we use the names Nannobrachium and Lampanyctus following Moser and Ahlstrom (1996) to designate larvae with a rostrum that is long and short, respectively.

On the basis of a number of characters, including elongated jaws, long rostrum, large head, large pectoral fins, and posteriorly displaced dorsal fin (Moser et al., 1984; Zahuranec, 2000), we assign these larvae to the genus Nannobrachium. A series of similar larvae of different sizes from the Pacific Ocean and from the tropical and subtropical Atlantic Ocean have been described (Ozawa, 1986; Moser and Watson, 2001). Our larvae differ from larvae collected in the Pacific Ocean only in the presence of a pigment row on the isthmus and anterior to the anus; our specimens have no differences from the larvae from the Atlantic Ocean. Moser and Watson (2001) suggest that a larva such as our specimens belongs to a species found in the Atlantic Ocean that is close to N. nigrum. Note that Zahuranec (2000), on the basis of adult characters, identified 5 phylogenetic groups within the genus Nannobrachium: the Nigrum, Regale, Cuprarium, Achirus, and Isaacsi species groups. Moser et al. (1984) also identified several groups according to larval characters: $L$. regalis- $L$. ater $(L$. regalis and $L$. ater are now considered synonyms of $N$. regale and $N$. atrum, respectively), L. lineatus- $L$. cuprarius (L. lineatus and $L$. cuprarius are now considered synonyms of $N$. lineatum and $N$. cuprarium, repectively), and $L$. achirus (now considered a synonym of $N$. achirus). The group $L$. lineatus- $L$. cuprarius is fully consistent with the species composition of the Cuprarium group described by Zahuranec (2000). The larvae of $N$. nigrum and $N$. atrum (Richards, 2005) have preopercular spines that are absent in other known larvae, and Zahuranec (2000) placed adults of both of these species in the Nigrum group. The morphotype of the larva that we are describing is characterized by the absence of preopercular spines.

We compared the pigmentation and plastic characters of our larvae with the larval characters used by Olivar and Beckley (1997) to construct a similarity matrix for the Lampanyctus larvae. The results of a comparison of characters indicate that our larva was closest to $N$. regale. The similarity is noticeable in 22 of 24 features, except for pigmentation on the dorsal tail and eye size. Therefore, we believe that they are the larvae of a species not yet described and that that they inhabit the tropical and subtropical Atlantic Ocean and, possibly, the western Pacific Ocean. Despite the existing correspondence between the groups established on the basis of larval and adult characters, the Regale group still has an important inconsistency: in the larvae of $N$. ritteri and $N$. idostigma, the jaws are not elongated, as they are in the larvae of other Nannobrachium species. The small number of species for which larvae of the genus Lampanyctus have been described prevents correlation between adult and larval groups of this genus.

\section{Lampanyctus vadulus}

Description A single larva was collected: $7.5 \mathrm{~mm} \mathrm{SL} \mathrm{(st.}$ 2657) (Fig. 6B). D: 14, A: 18, $\mathrm{P}_{1}: 12, \mathrm{P}_{2}: 5+, \mathrm{C}: 3+9-10+4$, GR: $4+1+9=14$, V: $36-37$, BrR: 8 . The larva has a deep body (BD $37 \%$ SL) and a large head (HL $40 \%$ SL) with long jaws extending beyond the vertical of the eye posterior margin. The snout is rather long ( $\mathrm{SnL} 33 \% \mathrm{HL}$ ), and the eye is round (ED 27\% HL). Anus opens slightly behind the middle of the body. The dorsal fin begins about the middle of the body (PDL 55\% SL) and has 14 rays. The anal fin starts under the 5-6 ray of the dorsal fin (PAL 62\% SL) and has 18 rays. The larva has several pigment spots at the upper and lower jaw tips, an unpaired melanophore above the forebrain, and large paired melanophores located posterolaterally to the midbrain. There is an internal melanophore anterior the dorsal fin base and a large unpaired melanophore located dorsally under the middle of the adipose fin base. Paired large melanophores are present on the dorsal side of the terminal gut section; the inner pigment is above the gas bladder. The pigment on the anterial side of the liver forms a strip.

Comparative remarks Habitually, the larva from our sampling is similar to the larvae of the genus Lampanyctus (for differences, see the "Comparative remarks" section for Nannobrachium sp. 1). Illustrated descriptions of similar larvae designated as Lampanyctus sp. 7 have been made for larvae from the western Pacific Ocean (Ozawa, 1986). In addition, in the IO RAS collections (5.5-mm-SL larva from st. 3737 and 2 larvae [5.4 and $5.5 \mathrm{~mm} \mathrm{SL}$ ] from st. 3708 of the 36 th cruise of the RV Kurchatov) taken in the Indian Ocean's equatorial part, we found larvae like our specimens (Fig. 6A). All of these larvae are identical, both in pigmentation and in meristic features (proportions of larvae from the Indian Ocean: BD 35\% SL, HL 38\% SL, SnL 39\% HL, ED 32\% HL, SAL 63\% SL, PDL 56\% SL); our 7.5-mm-SL larva differs only in the presence of a pigment series on the isthmus. According to Hulley (1981), Bekker (1983), and Wisner (1976), not a single known species of Lampanyctus inhabits the western Pacific Ocean, tropical Atlantic Ocean, or Indian Ocean. Among species whose 


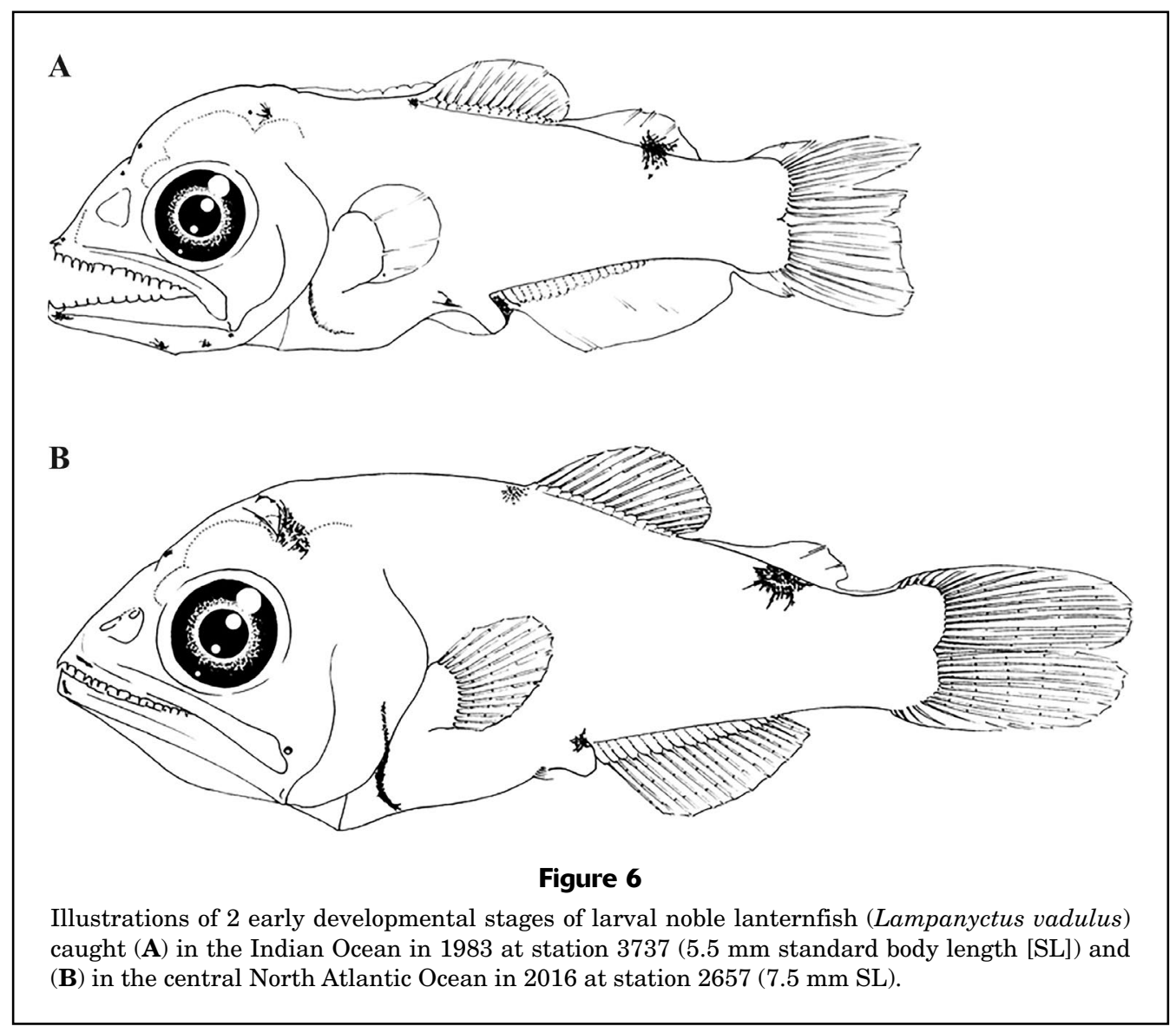

larvae are not described, only L. macropterus, which lives in the equatorial waters of the Pacific and Indian Oceans, has similar meristic characters (D: 13-15, A: 18-19, $\mathrm{P}_{1}$ : 13-15; GR: 13-15), and L. vadulus is the only one among the species in the Atlantic Ocean to have a central distribution type (Hulley, 1981; Bekker, 1983). Therefore, we preliminarily identify this larva as L. vadulus.

\section{Lampanyctus sp. 1}

Description Ten larvae were found in our collections: $8.0 \mathrm{~mm}$ SL (st. 2623), $8.4 \mathrm{~mm}$ SL (st. 2631), $8.7 \mathrm{~mm} \mathrm{SL}$ (st. 235), $6.6 \mathrm{~mm} \mathrm{SL} \mathrm{(st.} \mathrm{2175),} 3.2 \mathrm{~mm} \mathrm{SL} \mathrm{(st.} \mathrm{2176),}$ 5.5, 6.4, 6.9, $8.5 \mathrm{~mm}$ SL (st. 2183), $10.0 \mathrm{~mm}$ SL (st. 2193) (Fig. 7). D: 14, A: 17, $\mathrm{P}_{1}: 13-14, \mathrm{P}_{2}: 8, \mathrm{C}: 6+10-11+5$, GR: 4+1+9-10, V: 33-34, BrR: 8. Larvae are deep-bodied (BD $33-36 \%$ SL) with a large head (HL 30-36\% SL). The anus opens behind the middle of the body (PAL 65-66\% SL). Eyes are round and large (ED 34-39\% HL). The snout is pointed (SnL 26\% HL); in large larvae, the jaws reach the vertical of the eye posterior margin; and there are prominent teeth on both jaws with an anterior tooth patch on the upper one. The gut is relatively straight. The dorsal fin originates near the midbody (PDL 54-57\% SL). All the rays in fins are distinguishable in the 8.4-mmSL larva. Pigmentation consists of paired melanophores anterior to the midbrain and posterior to the hindbrain (SL >6.6 mm), 1 melanophore situated on the opercle and several on the cleithrum, 2-3 melanophores on the base of the pectoral fin, and 1 or more melanophores on the tips of jaws. Inner melanophores above the gas bladder are visible. With an increase in the size of the larvae, melanophores are added at myosepta between the pectoral and pelvic fins. $\mathrm{Br}_{2}$ photophores are already noticeable on the 6.4-mm-SL larva.

Comparative remarks Larvae were found in the subtropical zones of both the North and South Atlantic Ocean. Among the species in the Atlantic Ocean with this type of distribution, L. tenuiformis and L. photonotus are similar by the complex of meristic characters. However, the early stages of development of these species are known (Moser and Ahlstrom, 1996; Moser and Watson, 2001) and differ from those of our larvae in pigmentation especially. On the basis of the features applied by Olivar and Beckley (1997) to separate Lampanyctus larvae into groups, our larvae are closest to the second group, which includes L. parvicauda, L. idostigma, L. nobilis, L. ritteri, the jewel lanternfish (L. crocodilus), and L. australis, among others, but the larvae differ in pigmentation pattern from larvae of all known Lampanyctus species. Perhaps these larvae belong to a species not yet described. 


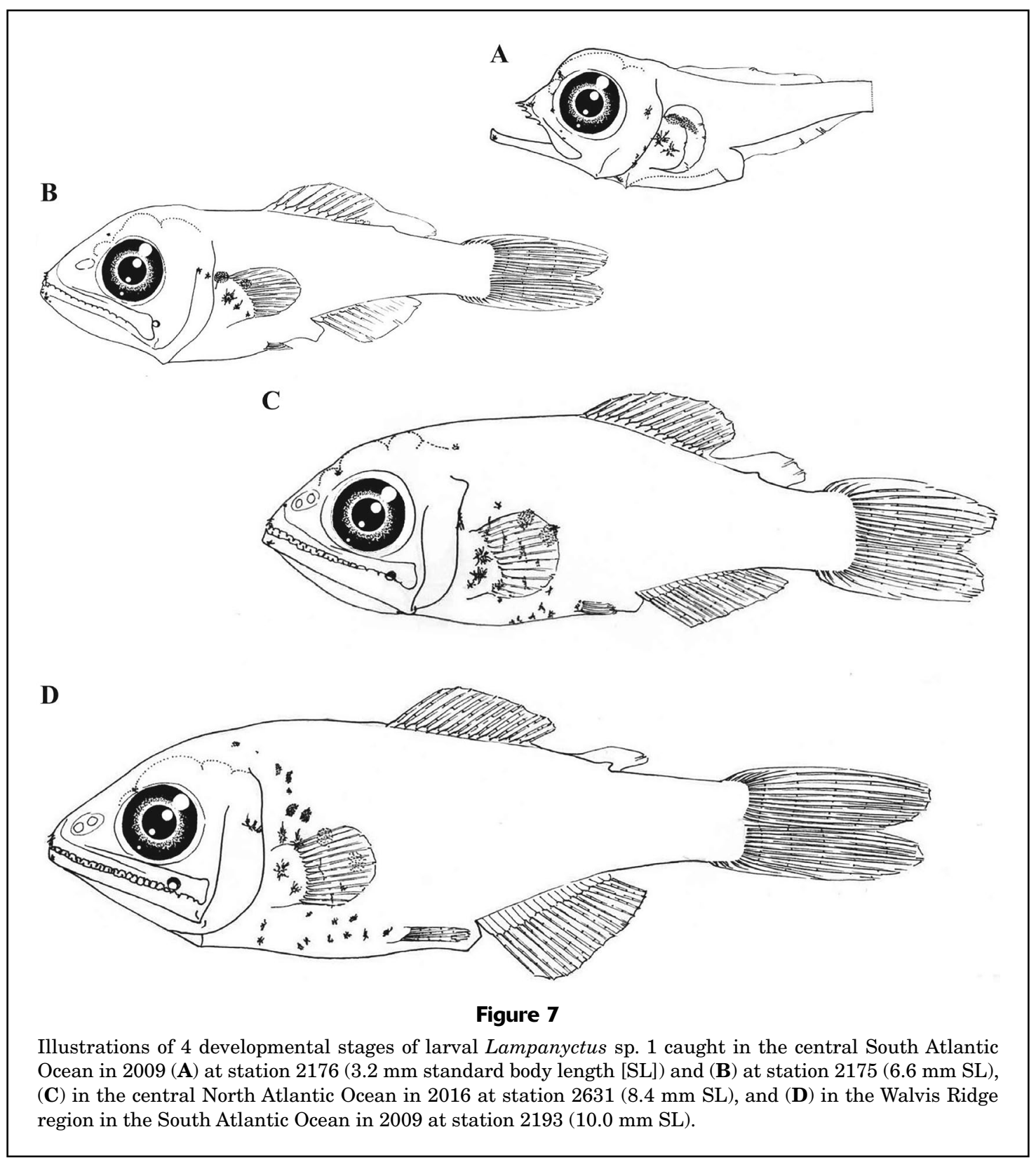

\section{Acknowledgments}

The authors are grateful to S. Kobylyansky (IO RAS) for the materials provided for the study. The study was supported by the state assignment of IO RAS no. 0149-2019-0009 and financially supported by the Russian Science Foundation (no. 19-14-00026).

\section{Literature cited}

Ahlstrom, E. H., H. G. Moser, and M. J. O’Toole.

1976. Development and distribution of larvae and early juveniles of the commercial lanternfish, Lampanyctodes hectoris (Günther), off the west coast of southern Africa with a discussion of phylogenetic relationships of the genus. Bull. South. Calif. Acad. Sci. 75:138-152.

Bekker, V. E.

1983. Myctophid fishes of the World Ocean, 248 p. Nauka, Moscow, Russia. [In Russian.]

Bolshakova, Ya. Yu., and S. A. Evseenko.

2016. On the species composition of ichthyoplankton of the Walvis Ridge (South Atlantic). J. Ichthyol. 56:848-860. Crossref

2020. Ichthyoplankton of the southern waters of the North Atlantic: 2. Species composition and distribution features. J. Ichthyol. 59:870-884. Crossref

Bonecker, A. C. T., and M. S. de Castro (eds.).

2006. Atlas de larvas de peixes da região central da Zona Econômica Exclusiva brasileira, Ser. Livros 19, 214 p. Museu Nacional, Rio de Janeiro, Brazil. [In Portuguese.] 
Fahay, M. P.

2007. Early stages of fishes in the western North Atlantic Ocean (Davis Strait, Southern Greenland and Flemish Cap to Cape Hatteras), vol. 1, 931 p. NAFO, Dartmouth, Canada.

Hulley, P. A.

1981. Results of the research cruises of FRV "Walther Herwig" to South America: 58. Family Myctophidae (Osteichthyes, Myctophiformes). Archiv. Fischereiwiss. 31(1):1-303.

Hulley, P. A., and G. Duhamel.

2009. A review of the lanternfish genus Bolinichthys Paxton, 1972 (Myctophidae). Cybium 33:259-304.

Kobyliansky, S. G.

2016. Anatomy of fishes of genus Lampanyctus (sensu lato), its taxonomic structure, and status in the Lampanyctini (Myctophidae) tribe system. J. Ichthyol. 56:181-199. Crossref

Kozlov, A. N.

1995. A review of the trophic role of mesopelagic fish of the family Myctophidae in the Southern Ocean ecosystem. CCAMLR Sci. 2:71-77.

Moser, H. G., and E. H. Ahlstrom.

1970. Development of lanternfishes (family Myctophidae) in the California Current. Part 1. Species with narrow-eyed larvae. Bull. Los Angel. Cty. Mus. Nat. Hist. Sci. 7, 145 p.

1972. Development of the lanternfish, Scopelopsis multipunctatus Brauer 1906, with a discussion of its phylogenetic position in the family Myctophidae and its role in a proposed mechanism for the evolution of photophore patterns in lanternfishes. Fish. Bull. 70:541-564.

1996. Myctophidae: lanternfishes. In The early stages of fishes in the California Current region (H. G. Moser, ed.), p. 387-475. CalCOFI Atlas 33.

Moser, H. G., and W. Watson.

2001. Preliminary guide to the identification of the early life history stages of Myctophiform fishes of the western central Atlantic. NOAA Tech. Memo. NMFS-SEFSC-453, 118 p.

Moser, H. G., E. H Ahlstrom, and J. R. Paxton.

1984. Myctophidae: development. In Ontogeny and systematics of fishes. Based on an international symposium dedicated to the memory of Elbert Halvor Ahlstrom; La Jolla, CA, 15-18 August 1983 (H. G. Moser, W. J. Richards, D. M. Cohen, M. P. Fahay, A. W. Kendall Jr., and S. L. Richardson, eds.), p. 218-239. Am. Soc. Ichthyol. Herpetol., Spec. Publ. 1.

Nafpaktitis, B. G., R. H. Backus, J. E. Craddock, R. L. Haedrich, B.

H. Robison, and C. Karnella.

1977. Family Myctophidae. In Fishes of the western North Atlantic. Part 7. Order Iniomi (Myctophiformes): neoscopelids, lanternfishes, and Atlantic mesopelagic zoogeograpy (R. H. Gibbs Jr., ed.), p. 13-265. Sears Found. Mar. Res., Yale Univ., New Haven, CT.

Olivar, M. P., and L. E. Beckley.

1997. Larval development of Lampanyctus species (Pisces: Myctophidae) from the Southwestern Indian Ocean, and species groups based on larval characters. Bull. Mar. Sci. 60:47-65.

Olivar, M. P., and J. M. Fortuño.

1991. Guide to the ichthyoplankton of the Southeast Atlantic (Benguela Current region). Sci. Mar. 55:1-383.

Olivar, M. P., H. G. Moser, and L. E. Beckley.

1999. Lanternfish larvae from the Agulhas current (SW Indian Ocean). Sci. Mar. 63:101-120. Crossref

Ozawa, T.

1986. Studies on the oceanic ichthyoplankton in the western North Pacific, 430 p. Kyushu Univ. Press, Fukuoka-shi, Japan.

Pertseva-Ostroumova, T. A.

1964. Some morphological characteristics of myctophid larvae (Myctophidae, Pisces). Tr. Inst. Okeanol. Akad. Nauk SSSR 73:79-97. [In Russian.]

Richards, W. J. (ed.)

2005. Early stages of Atlantic fishes: an identification guide for the western central North Atlantic, vol. 1, 1335 p. CRC Press, Boca Raton, FL.

Sabourenkov, E.

1992. Myctophids in the diet of Antarctic predators. In 1991 selected scientific papers. SC-CAMLR-SSP/8, p. 335-360. CCAMLR, Hobart, Australia.[Available from website.]

Sparta, A.

1952. Contributo alla conoscenza dello sviluppo larvale di Myctophum metopoclampum Cocco. Boll. Pesca Idriobiol. 7:5-10. [In Italian.]

Valinassab, T., G. J. Pierce, and K. Johannesson.

2007. Lantern fish (Benthosema pterotum) resources as a target for commercial exploitation in the Oman Sea. J. Appl. Ichthyol. 23:573-577. Crossref

Wisner, R. L.

1976. The taxonomy and distribution of lanternfishes (family Myctophidae) of the eastern Pacific Ocean. NORDA Rep. 3, 229 p. Navy Ocean Res. Dev. Act., Bay St. Louis, MS.

Zahuranec, B. J.

2000. Zoogeography and systematics of the lanternfishes of the genus Nannobrachium (Myctophidae: Lampanyctini). Smithson. Contrib. Zool. 607:69. Crossref 